\title{
Impact of Globalization on SMEs Export Business and Economy of Pakistan by Using CGE Model
}

\author{
Dr. Anwar Ali Shah G.Syed \\ Professor of Business Administration and Pro-Vice Chancellor, Dadu Campus \\ University of Sindh, Jamshoro, Pakistan \\ Dr. Khalid Hussain Shaikh \\ Associate Professor, Deptt: of Commerce \\ University of Sindh, Jamshoro, Pakistan \\ Dr.Tariq Mehmood \\ Assistant Professor, IER, University of the Punjab, Lahore, Pakistan
}

Miss. Tahira Afridi

Lecturer, IER, University of the Punjab, Lahore, Pakistan

Faiz Muhammad Shaikh

Assistant Professor

Deptt: Agri: Economics, SZABAC-Dokri, Pakistan

E-mail: faizmuhammed_2000@yahoo.com

Received: December 16, 2010 Accepted: February 26, $2011 \quad$ doi:10.5539/ass.v7n9p52

\begin{abstract}
This research investigates the Globalization impact on the SMEs export by using Computable General Equilibrium model. The main objectives of this research are to provide detailed overview of economic reforms in the last decade by using the General Equilibrium Model. Data were collected from 300 SMEs business exports in Pakistan by using simple random technique. Structural questionnaire is used as a basic tool for measuring export potential. Data from developing countries were collected through secondary sources and data were analysis by using Gem-Software. It was revealed that from last decade, globalization has positively revolutionized the SMEs export business the economy of Pakistan. The Global trade analysis Purdue (GTAP) model is used to analyze the possible impact of Globalization on Pakistan's economy in a multi-country, multi-sector applied General Equilibrium frame work. After employing the simplified static analysis framework based on simulations reveal that Globalization and FDI have influenced positively on the economy of Pakistan. The general inflation rate is decreased and living standard is increased in urban areas. Employment opportunities are also increasing due to the investment made by the FDI and as for as cultural context is concerned, Pakistani people are more reluctant to reduce the traditional cultural barriers. On the contrary side, other consumer items like leather-made and cotton-made garments will expand after the FTA and consumer surplus will increase. This perspective enables us to identify new challenges in the global economy and to identify the multiple routes through which power and resource inequalities are reproduced within it. More positively, it helps to identify new opportunities and routes to challenging these inequalities. The application of this perspective to the impact of the rapidly-growing economy in real increase in terms of trade.
\end{abstract}

Keywords: Globalization, Economy, CGE Model, Pakistan 


\section{Introduction}

Globalization is an umbrella term that describes an ongoing process of establishing various personal, cultural, and business relationships with other countries. This process embodies an increasing view of the world as a community. People and companies are interacting with others in different countries more than ever before. This includes personal communication between people that live on the other side of the world from each other. Companies are now striving to open markets in developing countries, instead of only delivering products and services domestically. (Technology is beginning to expand across nations. Information is being shared with a multitude of people throughout the world in a fraction of the time that it would take to contact someone down the hall from your office. There is a growing interdependence of one country on another. The process of globalization appears to be accelerating and growing rapidly. As time continues to pass, it appears that we are moving to a world where the lines that divide one country from another will begin to blur and eventually fade away entirely. Globalization - the growing integration of economies and societies around the world - has been one of the most hotly-debated topics in international economics over the past few years. Rapid growth and poverty reduction in China, India, and other countries that were poor 20 years ago, has been a positive aspect of globalization. But globalization has also generated significant international opposition over concerns that it has increased inequality and environmental degradation. This site provides access to some of the most recent presentations on globalization and some of the leading research on the subject. Globalization is a term that is used to describe the changing world order in which various aspects of a nation that include the economic, social, political, cultural and environmental factors are viewed as being part of a global community and not restricted in their scope. The term came to be used to describe the phenomenon of global flux in which trade as represented by capital and material can move freely across the world with lesser restrictions with respect to national boundaries. Globalization though it has been essentially connoted with economic issues synonymous with multi national companies (MNC) and their policies that directly or indirectly affect populations across the world has also consequently ushered in an era of change with respect to social and cultural matters inducing a competitive spirit in world culture for the better or worse according to the social fabric of various communities and their flexibility and adaptability. Knowledge, with respect to developments in science and technology is perceived to be the driving force behind globalization and continues to be the decisive factor what with the outsourcing trends of several MNCs to offshore destinations in recent times. Globalization has often been seen as being a subtle factor that tries to undermine welfare policies of governments across the world and individual choice and being elitist in nature but it has also unconsciously forced democratic nations to be more affirmative and inclusive with respect to the betterment of all sections of societies and also to address vital issues like the conservation of the environment.

In the area of employment creation, extrapolation from various sources suggests a possible direct employment effect of Globalization in developing countries of around 26 million jobs in 1997. Estimates of the indirect employment effect of FDI vary widely around a multiplier of 1.6 (i.e. 1.6 indirect jobs for every one direct job). Also, foreign-invested enterprises (FIEs) do generally pay higher wages than domestic companies, and even in low-wage, labor-intensive industries, FIE jobs are often considered better than the alternatives of unemployment or underemployment. However, investments in different industries clearly have different job-creation propensities which policymakers need to take into consideration. There is also an increasing recognition that ways of harnessing FDI to support small and medium enterprise (SME) sectors in developing countries, and associated employment creation, remain under-exploited. (Heien. D, and Wessells, C.R. et al. 1990) regarding employment practices, a key issue is the effect of FDI on female participation in the labor force. On the one hand, greater female employment at FIEs, in addition to helping level the playing field in terms of employment opportunities, results in a direct increase in household income and a higher proportion of income expended on meeting basic family needs. On the other hand, women are often paid less than men in comparable jobs, isolated from mainstream job advancement opportunities, and subject to greater employment instability. Another major issue is that of child labor, with subcontracting often making monitoring difficult, and many children serving as primary household earners. As a second-best solution to banning child labor and providing schooling instead, improved corporate governance on the part of governments, and improved corporate management on the part of companies are crucial. Progress in this area is a function of policy measures and their enforcement, and of greater dialogue and collaboration between the government and the (foreign and domestic) private sector.

It is a matter of fact that there are a lot of things in which large companies are experts while the small firms can better do some things also. If both, small and large firms do their business in which they get advantage, the welfare of the economy can be maximized and the state of specialization can be attained. When we focus on the 
impact of small as well as medium firms on the whole economy, it is difficult rather impossible for us to segregate their impacts from the impact of large corporations.

This issue remained a hot topic for centuries. Economists were of the view that it is a large firm, which participates actively in the economy and also shares a large amount of foreign exchange earnings. But their point of view changes when the countries like Taiwan, Japan and Korea developed on their small and medium based business. It is the crystal clear that these economies developed through the grass root level as small and medium enterprises belong to grass root. Those who believe that the large firms are only responsible for economic growth should keep in mind that the small vendors and small suppliers contribute heavily in the production of large firms. The reality on ground is that small firms are held responsible for making large firms to attain their targets. The progress and prosperity, which take place from the lower level, benefit all the classes of the society. The spill over impacts of SMEs proves to be ever lasting on the world's economy.

The situation differs in Pakistan. It is not more that 10 years that Govt. of Pakistan has established an institution named small and Medium Enterprise Authority (SMEDA) which is considered responsible to promote small and medium enterprises. SME sector is being neglected in Pakistan and so as the impacts of small and medium firms of Pakistan's economy. Pakistan is very potential market for SMEs and if undertaken in systematic way can prosper economy within no time. Sindh province has a considerable advantage in some areas which needs to be explained quickly to reap the benefits of exports. Such benefits can increase foreign exchange rates very positively to develop a favorable framework in all areas of progress.

The awareness like fishing, education, fruit, crops, garments, cotton, sugar cane, dates ginning, wood, auto and many other areas are the basic startups for many people. This research explains the potentialities of some areas and knowledge of how these areas can contribute towards Pakistan's economy by increasing the foreign exchange rates with reference to Sindh province. The high authorities and ministry of development and product should formulate some strategies to design practical policies with the cooperation of stakeholders, such policies will be flexible in enhancing the SMEDA plans and flourish SMEs activities at the larger scale. This will give a big boost to startup ideas and create cordial atmosphere of businesses. This will aid a lot more in understanding the export of Pakistan specially Sindh sector and improve our foreign exchange earnings._The main focus will be on SMEs' roles in economic growth and poverty alleviation through the increase of entrepreneurial and small scale business activities in the country especially in Sindh.

The third chapter provides a review of theoretical and empirical literature and the significant issues related to the understanding of Small and Medium Enterprises. Literature of Small \& Medium Enterprises is divided into two sections: International and National studies.

First section evaluates the existing international literature in regard to the development of SMEs, their role in economy specifically in exports, challenges and problems they are facing. Balasuriya (1992), Voerman, wedel and Zwart (1998), Muranda (2003), Hi Lin Hoon, Stoain (2007)'s studies support the concept of export oriented SMEs and highlight the positive relationship between Exports and SME's growth. While other studies by Majumder (2004), Kacker (2005), Saleh and Ndubisi (2006) and Tambunnan (2006) investigate the problems and challenges for SME's development. However, Branco (2003) argues the role and importance of small \& medium enterprises in economy.

National studies also correlate the presence of SMEs with several economic factors. Berry (1998), Mustafa and Khan (2005) and Khawaja (2006) outline the importance and potential of SME sector in Pakistan's economy. Husain (2003) discusses the role of SMEs in production of exports and the challenges they are facing in local market. Coy, Shipley, Omer and Khan (2007) determine the factors responsible for attaining success in small business in Pakistan.

The fourth chapter elaborates that SMEs constituted major share in the exports of Pakistan and contributing almost thirty percent to GDP on average during the time period of last five years. The main sectors included in SMEs were Footwear Industry, automotive parts, dairy industry, meat industry, leather industry, sports goods, fabrics, garments, bed wear, towels, tents and canvas, horticulture, cutlery, gems and jewellery, blankets and traveling rugs, furniture sector, pharmaceutical sector, services sector etc. Growth in SMEs sector has a direct impact on Pakistan's exports and vice versa, which is needed to be focused on priority basis.

The fifth chapter presents a glimpse of policies related to SME in Pakistan. It highlights the advantages and incentives given to SME sector in Pakistan and also throws light on the shortfalls in the policy formulation and implementation. It also provides a comparative study of policies related to small and medium enterprises in different countries. In the last chapter some recommendations and proposals have been made for the improvement and development of the small \& medium enterprises in Pakistan. 


\section{Methodology}

\section{Data Collection and Research Methodology}

Data were collected from 300 SMEs business exports in Pakistan by using simple random technique and Structural questionnaire is the basic tool for measuring export potential. Data from developing countries were collected through secondary sources and data were analysis by using Gen-Stat-statistical software. The sources of the data are various issues of Economic Survey of Pakistan, database of Small \& Medium Enterprises (SMEDA), publication of International Trade Centre (ITC), annual reports of State bank of Pakistan, database of Trade Development Authority of Pakistan (TDAP), publications and databases of Federal Bureau of Statistics, trade polices from Ministry of Commerce of Pakistan, databases of Ministry of Finance, etc. Literature covers the research papers and studies available on the subject on internet and journals and libraries. The study is an attempt to present comparative analysis of the various SME based economies in the world specifically from Asia.

Model: The Micro simulation method proposed in this paper relationship of both a CGE model and Household model. What distinguish from this model from the work of (Janvry et al .1992), (Ajitha et at 2004-05) and (Bourguignon et al 2000). Is its bi directional relationship. The model line Globalization and its impact on economy of Pakistan and poverty on both household and rural spending.

\section{Description of the Model}

Model 1. Globalization impact on SMEs export laid Growth

\section{Computable General Equilibrium Model (CGE).}

To compare the impact of Globalization on rural and urban population we started with the simple model, which however integers all the standard characteristics of the CGE model of small under developed country. The demand system is derived from the Cobb Douglas utility function with two factors of Globalization and poverty relationship. Regarding the household model we have an income function consisting of rural projects of FDI and their general impact on the rural households on consumption.

\section{Results Analysis SMEs export laid Growth}

We only performed one simulation to illustrate the approach's contribution. Different simulation has been tested to verify whether the conclusions reached in terms of impact of Globalization on SMEs business in Pakistan.

Table 2 shows production of automotive sector during last thirteen years.

\section{Leather Industry}

(Finished Leather, 2002) stated that world's leading exporters of finished leather were Italy, Republic of Korea, Argentina, USA, Germany and Brazil. Further, Hong Kong, Italy, Germany, Spain and France were important buyers of finished leather from Pakistan in 2002. During 2002, Kasur (223) was main cluster city of finished leather in Pakistan followed by Sialkot (210), Karachi (174), Gujranwala (51), Multan (43), Sheikhupura (28), Lahore (15), Sahiwal (8), Faisalabad (7), Peshawar (6), Sargodha (5) etc.

Following Table shows export of Leather Products during 2001-06. Export of leather Tanned shows variation during 2001-06 as shown in Figure. Exports of leather tanned decreases from US\$239,934 thousand in 2001-02 to US $\$ 234,774$ thousand in 2002-03 showing fall in exports by 2.15 percent during the same time period. Then, again exports of leather tanned shows increasing trend in two consecutive years of 2003-04 and 2004-05 by 7.21 percent and 20.63 percent respectively. However, it depicts decrease by 3.69 percent in 2005-06.

In the Table 3.6 export of leather gloves from Pakistan shows increasing trend except the year of 2005-06. In 2005-06 export of leather gloves stood at US\$ 151,459 thousand as compare to US\$164,333 thousand in 2004-05 decreased by 7.8 percent during the same time period. Major buyers of Pakistan for the product of leather gloves are USA, Germany and France with their share at 22.99 percent, 11.64 percent and 7.85 percent respectively in 2005-06.

Export of leather products in the category of apparel \& clothing increased except 2002-03. The value of Export of Pakistan in this product stood at US\$ 501,786 thousand in 2005-06 as compare to US\$ 321,341 thousand in 2001-02, with an increase of 56.15 percent over the period. While Pakistan's export of leather manufactures n.s. shows growth of 558.21 percent during 2001-06.

\section{Conclusion}

The purpose of this paper to analysis the impact of Globalization on economy of Pakistan by using CGE frame work. We started with the comparative exercise of Globalization and its role in reducing poverty in Pakistan. The 
Household Model this model limited only capture the heterogeneity element in household behavior. There are two main factors Globalization and their impact on GDP and economic growth. In the second model linear expenditure system (LES) replaces the demand of system derived from Cobb-Douglas utility function. This exercise highlighted the contribution household disaggregating in the context of CGE modeling exercise and marginal contribution of introducing the heterogeneity elements. According to the results Globalization has significant impact on the economy of Pakistan. CGE Model has been gaining importance in policy analysis of the inequalities of poverty. Globalizations policies can affect in not only improve the economic growth but also help in poverty reduction policies. The task of the policymaker is to coordinate policies affecting the two areas in such a way as to optimize the contribution of Globalization to alleviate poverty in Pakistan. The overall in-depth sample showed a high degree of concern over economic problems but that concern did vary. The constraint which was most uniformly faced was political instability followed by (the related constraint) uncertainty in the business climate. Those in Sindh were significantly more concerned about their lack of information on their competition and about the lack of market for their products than their peers in Punjab or NWFP. Even more dramatically, all those interviewed in Sindh were severely threatened by uncertainty in the business climate and by climatic disasters while their colleagues elsewhere were much less likely to rank these as serious constraints. More than $80 \%$ of them thought that government corruption was serious problem for them as well.

\section{References}

(2000). Small and Medium Enterprises in Hong Kong, Reforms from Developing Countries. Export Orientation for Small and Medium Enterprises in Exports, APO.

Akizawa, Hikari. \& Kijima, Kyoichi, Kijima. Theory \& Research: Internet-based Entrepreneurial Networking to Evolve the Japanese Industrial Structure. Department of Value and Decision Science, Tokyo Institute of Technology, Japan.

Balasuriya, Anton. (2 ${ }^{\mathrm{ND}}$ QTR/1992). Technonet Asia, Newsletter, Singapore.

Bardrinath, R. (1997). The SME and the Global Market Place. International Trade Centre UNCTAD/WTO Geneva, Switzerland.

Castel-Branco, \& Carlos Nuno. (2003). A Critique of SME-led Approaches to Economic Development. Islamic Chamber of Trade and Industry, Mozambique.

Chen, Edward K.Y. (1986). Small Industry in Asia's Export- Oriented Growth. Asian Productivity Organization, Tokyo.

Coy, Steven P, Shipley, Margaret F, Omer, Khursheed, \& Khan, Rao Nisar A. (2007). Factors Contributory To Success: A Study Of Pakistan's Small Business Owners. Journal of Developmental Entrepreneurship.

Edwards, Tim., Rick Delbridge and Max Munday. (2005). Understanding Innovation in Small and medium-sized Enterprises: A Process Manifesto. Cardiff University, Aberconway Building, Colum Drive, Cardiff CF 103 EU, UK.

Federal Bureau of Statistics. (2005). Pakistan Statistical Year Book.

Germidis, D. (1980). International subcontracting: a new form of investment. OECD, Paris.

Government of Pakistan, Small and Medium Enterprise Development Authority (SMEDA). Sector Brief: Dairy.

Government of Pakistan, Small and Medium Enterprise Development Authority (SMEDA). Sector Brief: Cutlery, Revised on July 12, 2002.

Halbach, AJ. (1989). Multinational enterprises and subcontracting in the third world: a study of inter-industry linkages. International Labour Office, Geneva.

Hoon, Ho Lin. Internationalization of Small Industry. National Productivity Board, Singapore.

Howard, Robert. (1990). Can Small Business Help Countries Compete? Harvard Business Review November-December 1990 (pp 80-103)

Husain, Ishrat. (2004). Financial Sector Reforms and Pro Poor Growth: a case Study of Pakistan Presidential Address at the Annual General Meeting of the Institute of Bankers Pakistan held at Karachi.

Husain, Ishrat. (2005). SME Financing Issues and Strategies. Welcome Address at the conference on SME Financing Issues and Strategies held in Lahore on May 9.

Jaitle, T.N. (1981). Export Promotion of Selected Small Industry Products: Asian Experience. Asian Productivity Organization, Tokyo. 
Kacker Stuti. (2005). Overcoming Barriers to Innovation for Indian SMEs. Ministry Small Scale Industries, New Delhi, India.

Khawaja, Shoaib. (2006). Unleashing the Growth Potential of SMEs in Pakistan through Productivity Enhancement. Pakistan Development Forum - 2006.

Kim, Young-Duck. (2000). Policies, Reforms and Evaluation of SME Export Experiences of Republic of Korea. Export Orientation for Small and Medium Enterprises in Exports, APO.

Klerg, GJ de. \& Havenga, JJD. SME Networks and Clusters and their Impact on Economic Growth: An Explanatory Overview of Africa. North-West University, Potchefstroom, South Africa.

Kohata., K. (2006). SME Policy in USA, Japan, Korea and Thailand. The Asian Development Bank (ADB) May 2006.

Majumder, Rajarshi. (2004). Productivity Growth in Small Enterprises - Role of Inputs, Technological Progress and Learning By Doing. MPRA Paper No. 4848, West Bengal.

Manjor, Asir. (2002). Garment Industry in Pakistan, In Gopal Joshi (eds.) Garments Industry in South Asia Rags or Riches?: Competitiveness, productivity and job quality in the post-MFA environment. India: International labour organization 2002.

Mcclean, Rowan, Wajid, \& Majid Ali. (February 2007). Services Exports: National Road Map for Pakistan Geneva, Switzerland: International Trade Centre (UNCTAD/WTO).

Muranda, Zororo. (2003). Relationships Between Firm Characteristics and Export Constraints in SME Exporters. Business Studies Deportment, University of Zimbabwe.

Nihaya, Wongtada. (2000). Opportunity and Threat to Potential SME Export: Experience of Thailand. Export Orientation for Small and Medium Enterprises in Exports, APO.

Office of SMEs Promotion (OSMEP)/ DIP/MOI and Institute for SMEs Development (ISMBD), Thailand. [Online] Available: www.sme.go.th \& www.smethai.net

Pakistan Automotive Manufacturer Association (PAMA), Data Base, 2005-06.

Paskaleva, K., Shapira, G. (2006). Innovation and SMEs: Some Asian Experiences. [Online] Available: http://www.itas.fzk.de/tatup/061/pash06a.htm.

Pichler, J. Hanns. \& Peter Voithover. (2006). SME Strategic Behavior and Attitudes towards Cooperation and Network. University of Lapland, Rovaniemi, Finland.

Saleh, Ali Salman and Ndubisi, Nelson Oly. (2006). An Evaluation of SME Development in Malaysia. International Review of Business Research Papers: 1-14. Malaysia.

Saxenian, A. (1994). Regional Advantage. MA: Harvard University Press.

Scholar, Morten, Bijil, Bastiaan, Butt Madiha and Haque, Inaam ul. (September 2007). The Sports Goods Sector In Pakistan: Export Performance And Potential \& Implication Of The WTO Agreements Geneva, Switzerland: International Trade Centre (UNCTAD/WTO).

Scholar, Morten, Elferink, Jan Oude, Bijil Bastiaan, Butt Madiha and Haque, Inaam ul. (September 2007). The Automotive Parts Sector In Pakistan: Export Performance And Potential \& Implication Of The WTO Agreements Geneva, Switzerland: International Trade Centre (UNCTAD/WTO).

Scholar, Morten, Lodhi, Javed, Roofthooft, Ward, Bijil, Bastiaan, Butt Madiha and Haque, Inaam ul. (August 2007). The Pharmaceutical Sector In Pakistan: Export Performance And Potential \& Implication Of The WTO Agreements Geneva, Switzerland: International Trade Centre (UNCTAD/WTO).

Scholar, Morten, Tissari, Jukka, Bijil Bastiaan, Butt Madiha and Haque, Inaam ul. (August 2007). The Furniture Sector In Pakistan: Export Performance And Potential \& Implication Of The WTO Agreements Geneva, Switzerland: International Trade Centre (UNCTAD/WTO).

Scholar, Morten, Zakaria, Fasim, Bijil Bastiaan, Butt Madiha and Haque, Inaam ul. (September 2007). The Footwear Sector In Pakistan: Export Performance And Potential \& Implication Of The WTO Agreements Geneva, Switzerland: International Trade Centre (UNCTAD/WTO).

Small and Medium Business Administration (SMBA). Korea. [Online] Available: www.smba.go.kr

Small and Medium Enterprise Agency (SMEA). Japan. [Online] Available: www.chusho.meti.go.jp

Small and Medium Enterprise Authority (SMEDA). [Online] Available: www.smeda.org.pk 
Stoian, Maria-Cristina. Managerial Determinants And Their Influence Upon The Export Behavior Of The Firm Case-Studies Of Catalan Exporting SMEs. Spain: University of Barcelona.

Tambunnan, Tulus. (2007). Trade and Investment Liberalization Effects on SME Development: A literature Review and a Case Study of Indonesia. Asia-Pacific Research and Training Network on Trade 42: Indonesia.

The OECD Small and Medium Enterprises Outlook, Country Profiles; Japan, Korea, Turkey, OECD.

Trade Development Authority of Pakistan, TDAP, Export Summary (2005-06) [Online] Available: http://www.epb.gov.pk

Trade Map, Data Base, 2006.

Voerman, J.A., Wedel, M. and Zwart, P.S. (1998). Export Market Information Behavior of SMEs: The Influence of Firm Characteristics. SOM Research School: University of Groningen.

Wang, Dr. Yue. (2007). Towards A Conceptualization of International Subcontracting. Monash Business Review Volume 3 Issue 1-April 2007. School Of Organization and Management, University of New South Wales. April 2007.

Winkelmann, Thorsten. (1996). Internationalization Strategies of Small and Medium-Sized Suppliers in a Global Economy. University of Gottingen, Gottingen, Germany.

Model 1. Globalization and Impact on Economy of Pakistan

\begin{tabular}{|l|l|l|l|l|l|l|l|l|}
\hline $\begin{array}{l}\text { Vari } \\
\text { ables }\end{array}$ & Base Value & $\begin{array}{l}\text { Model . } \\
1-\mathrm{AR}\end{array}$ & $\begin{array}{l}\text { Rural } \\
\text { W1 }\end{array}$ & $\begin{array}{l}\text { Mode } \\
12 \\
\text { FH }\end{array}$ & $\begin{array}{l}\text { Urban } \\
\text { Poverty }\end{array}$ & $\begin{array}{l}\text { Mode } \\
1 \\
\text { U-C }\end{array}$ & Change \\
\hline W2 & Informal wages & 0.1 & NA & NA & NA & NA & NA & NA \\
\hline Mps & $\begin{array}{l}\text { Marginal propensity } \\
\text { to save }\end{array}$ & 0.1 & 0.5 & -0.2 & 0.3 & +0.5 & +0.6 & 0.6 \\
\hline FDI & $\begin{array}{l}\text { Foreign direct } \\
\text { investment }\end{array}$ & 20900000 & 0.3 & -0.4 & -0.6 & +0.54 & 0.58 & 0.5 \\
\hline GDP & $\begin{array}{l}\text { Gross domestic } \\
\text { Product }\end{array}$ & 15265435.1 & 0.01 & $-0.2 \mathrm{~S}$ & -0.5 & +0.57 & 0.57 & 0.33 \\
\hline Rh & $\begin{array}{l}\text { Rural household } \\
\text { consumption }\end{array}$ & 1455676776 & 0.25 & 0.24 & -0.25 & +0.787 & 0.56 & 0.44 \\
\hline Uc & $\begin{array}{l}\text { Urban house hold } \\
\text { consumption }\end{array}$ & 324355455 & 0.55 & 0.88 & -.25 & +0.75 & 0.88 & 0.55 \\
\hline
\end{tabular}

Table 1. Contribution of SME in Manufacturing and GDP of Pakistan

(Percentage)

\begin{tabular}{|c|c|c|c|}
\hline Year & SME as a percentage of GDP & $\begin{array}{c}\text { Percentage share of } \\
\text { SME Manufacturing } \\
\text { in Value Addition }\end{array}$ & $\begin{array}{c}\text { SME as a percentage } \\
\text { of Industrial Labour }\end{array}$ \\
\hline $1994-95$ & 5.79 & 31.26 & 81 \\
\hline $1995-96$ & 5.90 & 32.8 & 80 \\
\hline $1996-97$ & 4.7 & 27 & 80 \\
\hline $1997-98$ & - & 35 & 80 \\
\hline $1998-99$ & 5 & - & 80 \\
\hline $1999-00$ & - & - & - \\
\hline $2000-01$ & - & - & 80 \\
\hline $2001-02$ & 30 & 30 & 80 \\
\hline $2002-03$ & 30 & & \\
\hline
\end{tabular}

Source: Economic Survey of Pakistan, Various Issues 
Table 2. Production of Automotive Sector during 1995-06

\begin{tabular}{|l|r|r|r|r|r|r|r|r|}
\hline Year & Cars & Trucks & Bus & Jeep \& LCV & Pic-Up/LCV & Farm Tractor & Motor Cycles \\
\hline $\mathbf{1 9 9 5 - 9 6}$ & 33,419 & 2,994 & 474 & 2,274 & 2,682 & 16,093 & - \\
\hline $\mathbf{1 9 9 6 - 9 7}$ & 37,032 & 2,917 & 456 & 792 & 4,553 & 10,417 & 106,797 \\
\hline $\mathbf{1 9 9 7 - 9 8}$ & 38,676 & 1,683 & 591 & 657 & 4,843 & 14,144 & 92,978 \\
\hline $\mathbf{1 9 9 8 - 9 9}$ & 42,927 & 1,083 & 1,124 & 622 & 3,834 & 26,644 & 87,504 \\
\hline $\mathbf{1 9 9 9 - 0 0}$ & 35,332 & 913 & 1,460 & 380 & 3,785 & 24,559 & 86,959 \\
\hline $\mathbf{2 0 0 0 - 0 1}$ & 41,556 & 912 & 1,326 & 459 & 4,982 & 31,635 & 108,850 \\
\hline $\mathbf{2 0 0 1 - 0 2}$ & 42,679 & 1,134 & 1,086 & 564 & 5,900 & 23,801 & 120,627 \\
\hline $\mathbf{2 0 0 2 - 0 3}$ & 66,432 & 1,929 & 1,296 & 374 & 7,815 & 26,240 & 175,169 \\
\hline $\mathbf{2 0 0 3 - 0 4}$ & 103,662 & 2,022 & 1,380 & 807 & 8,888 & 35,770 & 303,383 \\
\hline $\mathbf{2 0 0 4 - 0 5}$ & 133,722 & 3,204 & 1,762 & 1,564 & 16,294 & 43,200 & 416,189 \\
\hline $\mathbf{2 0 0 5 - 0 6}$ & 170,487 & 4,518 & 825 & 2,472 & 19,152 & 48,887 & 520,124 \\
\hline
\end{tabular}

(No.)

Source: PAMA

Table 3. Export of dairy products from Pakistan during 1999-04

\begin{tabular}{|c|c|c|c|}
\hline Year & Milk and cream & Butter & Eggs \\
\hline $1999-00$ & 54,517 & 1,560 & 18,631 \\
\hline $2000-01$ & 79,445 & 3,621 & 68,627 \\
\hline $2001-02$ & 102,247 & 5,770 & 112,072 \\
\hline $2002-03$ & 290,488 & 5,578 & 90,238 \\
\hline $2003-04$ & 444,506 & 3,003 & 113,534 \\
\hline
\end{tabular}

Source: Pakistan Statistical Year Book, 2005

Table 4. Export of Leather Products from Pakistan during 2001-06

(US\$ 000)

\begin{tabular}{|l|c|c|c|c|c|c|c|c|}
\hline Year & \multicolumn{2}{|c|}{ Leather Tanned } & \multicolumn{2}{|c|}{ Leather Gloves } & \multicolumn{2}{c|}{$\begin{array}{c}\text { Apparel \& Clothing } \\
\text { of Leather }\end{array}$} & \multicolumn{2}{c|}{$\begin{array}{c}\text { Leather } \\
\text { Manufactures N.S. }\end{array}$} \\
\cline { 2 - 10 } & Value & $\begin{array}{c}\text { Quantity } \\
(000 \mathrm{SQM})\end{array}$ & Value & $\begin{array}{c}\text { Quantity } \\
(000 \mathrm{DOZ})\end{array}$ & Value & $\begin{array}{c}\text { Quantity } \\
(000 \mathrm{DOZ})\end{array}$ & Value & Quantity \\
\hline $2001-02$ & 239,934 & 17,290 & 51,324 & 2,943 & 321,341 & 783 & 10,530 & - \\
\hline $2002-03$ & 234,774 & 15,349 & 56,969 & 2,718 & 232,316 & 564 & 97,262 & - \\
\hline $2003-04$ & 251,693 & 16,050 & 70,722 & 2,709 & 323,656 & 709 & 19,965 & - \\
\hline $2004-05$ & 303,606 & 18,435 & 164,333 & 5,649 & 329,272 & 737 & 33,169 & - \\
\hline $2005-06$ & 292,394 & 17,377 & 151,459 & 4,498 & 501,786 & 1,050 & 69,309 & - \\
\hline
\end{tabular}

Source: Trade Development Authority of Pakistan, TDAP $<$ http://www.epb.gov.pk $>$ 
Table 5. Export of Sports Goods from Pakistan during 2001-06

\begin{tabular}{|c|c|c|}
\hline Year & Sports Goods & \% Change \\
\hline $2001-02$ & 304,478 & - \\
\hline $2002-03$ & 335,173 & 10.08 \\
\hline $2003-04$ & 324,751 & $(3.11)^{*}$ \\
\hline $2004-05$ & 307,129 & $(5.43)$ \\
\hline $2005-06$ & 343,329 & 11.79 \\
\hline
\end{tabular}

* Figures in brackets shows negative values

Source: Trade Development Authority of Pakistan, TDAP <http://www.epb.gov.pk>

Table 6. Export of Fabrics from Pakistan during 2001-06

(US\$ 000)

\begin{tabular}{|c|c|c|c|c|}
\hline Year & Cotton Fabrics & $\begin{array}{c}\% \text { Change of } \\
\text { Cotton } \\
\text { Fabrics }\end{array}$ & $\begin{array}{c}\text { Knitted/Croacheted } \\
\text { Fabrics }\end{array}$ & $\begin{array}{c}\text { \%Change } \\
\text { Knitted/Croach } \\
\text { eted Fabrics }\end{array}$ \\
\hline $2001-02$ & $1,130,828$ & - & 72,420 & - \\
\hline $2002-03$ & $1,345,650$ & 19 & 59,466 & $(17.89)^{*}$ \\
\hline $2003-04$ & $1,711,492$ & 27.19 & 54,923 & $(7.64)$ \\
\hline $2004-05$ & $1,862,886$ & 8.85 & 187,158 & 240.76 \\
\hline $2005-06$ & $2,108,183$ & 13.17 & 51,378 & 72.55 \\
\hline
\end{tabular}

* Figures in brackets shows negative values

Source: Trade Development Authority of Pakistan, TDAP $<$ http://www.epb.gov.pk $>$

Table 7. Export of Garments from Pakistan during 2001-06

(US\$ 000)

\begin{tabular}{|c|c|c|c|c|}
\hline Year & $\begin{array}{c}\text { Ready-Made } \\
\text { Garments excl. } \\
\text { Leather } \\
\text { Garment }\end{array}$ & $\begin{array}{c}\text { \% change } \\
\text { Ready-Made } \\
\text { Garments excl. } \\
\text { Leather } \\
\text { Garment }\end{array}$ & Knitwear (Hosiery) & $\begin{array}{c}\text { \% Change Knitwear } \\
\text { (Hosiery) }\end{array}$ \\
\hline $2001-02$ & 874,954 & - & 845,943 & - \\
\hline $2002-03$ & $1,092,607$ & 24.88 & $1,146,674$ & 35.55 \\
\hline $2003-04$ & 993,322 & $(9.09)^{*}$ & $1,458,736$ & 27.21 \\
\hline $2004-05$ & $1,087,954$ & 9.53 & $1,635,033$ & 12.09 \\
\hline $2005-06$ & $1,309,990$ & 20.41 & $1,751,494$ & 7.12 \\
\hline
\end{tabular}

* Figures in brackets shows negative values

Source: Trade Development Authority of Pakistan, TDAP <http://www.epb.gov.pk> 
Table 8. Export of Bed Wear from Pakistan during 2001-06

(US\$ 000)

\begin{tabular}{|c|c|c|}
\hline Year & Bed Wear & \% Change Bed Wear \\
\hline $2001-02$ & 918,558 & - \\
\hline $2002-03$ & $1,329,064$ & 44.69 \\
\hline $2003-04$ & $1,383,334$ & 4.08 \\
\hline $2004-05$ & $1,449,533$ & 4.79 \\
\hline $2005-06$ & $2,038,064$ & 40.60 \\
\hline
\end{tabular}

Source: Trade Development Authority of Pakistan, TDAP $<$ http://www.epb.gov.pk $>$

Table 9. PART-1

\begin{tabular}{|c|c|c|}
\hline & Frequency & Percent \\
\hline Missing & $\mathbf{5 1}$ & $\mathbf{1 0 0 . 0}$ \\
\hline
\end{tabular}

Table 10. Nature of the Business

\begin{tabular}{|c|c|c|c|c|c|}
\hline & & Frequency & Percent & Valid Percent & $\begin{array}{c}\text { Cumulative } \\
\text { Percent }\end{array}$ \\
\hline \multirow[t]{11}{*}{ Valid } & \multirow{11}{*}{\begin{tabular}{l}
\multicolumn{1}{c}{ Bicycles } \\
Fabrication/M'facture \\
Food Processing \\
Footwear \\
Fruits \& vegetables \\
Jewellery \& Gems \\
Knitwear \\
OEM \\
Sports goods \\
Surgical \\
Total
\end{tabular}} & 3 & 5.9 & 5.9 & 5.0 \\
\hline & & 11 & 21.6 & 21.6 & 27.0 \\
\hline & & 7 & 13.7 & 13.7 & 41.0 \\
\hline & & 4 & 7.8 & 7.8 & 49.0 \\
\hline & & 4 & 7.8 & 7.8 & 56.0 \\
\hline & & 4 & 7.8 & 7.8 & 64.0 \\
\hline & & 5 & 9.8 & 9.8 & 74.0 \\
\hline & & 5 & 98 & 9.8 & 84.0 \\
\hline & & 3 & 5.9 & 5.9 & 90.0 \\
\hline & & 5 & 9.8 & 9.8 & 100.0 \\
\hline & & 51 & 100.0 & 100.0 & \\
\hline
\end{tabular}

Table 11. Type of Ownership

\begin{tabular}{|c|c|c|c|c|c|}
\hline & & Frequency & Percent & Valid Percent & $\begin{array}{c}\text { Cumulative } \\
\text { Percent }\end{array}$ \\
\hline \multirow[t]{5}{*}{ Valid } & \multirow{5}{*}{$\begin{array}{l}\text { Proprietorship } \\
\text { Partnership } \\
\text { Private Ltd } \\
\text { Public Ltd } \\
\text { Total }\end{array}$} & 23 & 45.1 & 45.1 & 45.1 \\
\hline & & 8 & 15.7 & 15.7 & 60.8 \\
\hline & & 18 & 35.3 & 35.3 & 96.1 \\
\hline & & 2 & 3.9 & 3.9 & 100.0 \\
\hline & & 51 & 100.0 & 100.0 & \\
\hline
\end{tabular}


Table 12. Local Share

\begin{tabular}{|cc|c|c|c|c|}
\hline & Frequency & Percent & Valid Percent & $\begin{array}{c}\text { Cumulative } \\
\text { Percent }\end{array}$ \\
\hline \multirow{2}{*}{ Valid } & $\mathbf{3 0 \%}$ & $\mathbf{1}$ & $\mathbf{2 . 0}$ & $\mathbf{2 . 0}$ & $\mathbf{2 . 0}$ \\
\cline { 3 - 6 } & $\mathbf{5 0 \%}$ & $\mathbf{2}$ & $\mathbf{3 . 9}$ & $\mathbf{3 . 9}$ & $\mathbf{5 . 9}$ \\
\cline { 3 - 6 } & $\mathbf{1 0 0 \%}$ & $\mathbf{4 8}$ & $\mathbf{9 4 . 1}$ & $\mathbf{9 4 . 1}$ & $\mathbf{1 0 0 . 0}$ \\
\cline { 3 - 6 } & Total & $\mathbf{5 1}$ & $\mathbf{1 0 0 . 0}$ & $\mathbf{1 0 0 . 0}$ & \\
\hline
\end{tabular}

Table 13. Foreign Share

\begin{tabular}{|c|c|c|c|c|c|}
\hline & & Frequency & Percent & Valid Percent & $\begin{array}{c}\text { Cumulative } \\
\text { Percent }\end{array}$ \\
\hline \multirow{3}{*}{$\begin{array}{c}\text { Valid } \\
\text { Missing } \\
\text { Total }\end{array}$} & \multirow{3}{*}{$\begin{array}{c}50 \% \\
\text { System }\end{array}$} & 2 & 3.9 & 100.0 & 100.0 \\
\hline & & 49 & 96.1 & & \\
\hline & & 51 & 100.0 & & \\
\hline
\end{tabular}

Table 14. What percentage of Your Materials and Parts are Imported?

\begin{tabular}{|c|c|c|c|c|c|}
\hline & & Frequency & Percent & Valid Percent & $\begin{array}{c}\text { Cumulative } \\
\text { Percent }\end{array}$ \\
\hline \multirow[t]{6}{*}{ Valid } & \multirow{2}{*}{$\begin{array}{l}50-80 \% \\
30-50 \%\end{array}$} & 6 & 11.8 & 13.0 & 13.0 \\
\hline & & 13 & 25.5 & 28.3 & 41.0 \\
\hline & \multirow{5}{*}{$\begin{array}{c}10-30 \% \\
\text { Less than } 10 \% \\
\text { Nil } \\
\text { Total } \\
\text { System }\end{array}$} & 7 & 13.7 & 15.2 & 56.0 \\
\hline & & 19 & 37.3 & 41.3 & 97.0 \\
\hline & & 1 & 2.0 & 2.2 & 100.0 \\
\hline & & 46 & 90.2 & 100.0 & \\
\hline \multirow{2}{*}{$\begin{array}{c}\text { Missing } \\
\text { Total }\end{array}$} & & 5 & 9.8 & & \\
\hline & & 51 & 100.0 & & \\
\hline
\end{tabular}

Table 15. Production Technology Training

\begin{tabular}{|l|l|c|c|c|c|}
\hline \multirow{3}{*}{} & & Frequency & Percent & Valid Percent & $\begin{array}{l}\text { Cumulative } \\
\text { Percent }\end{array}$ \\
\hline \multirow{5}{*}{ Valid } & & & & & \\
& Very Useful & 2 & 3.9 & 4.3 & 4.0 \\
\cline { 2 - 6 } & Quite Useful & 6 & 11.8 & 12.8 & 17.1 \\
\cline { 2 - 6 } & Not Useful & 16 & 31.4 & 34.0 & 51.0 \\
\cline { 2 - 6 } & Not Available & 23 & 45.1 & 48.9 & 100.0 \\
\hline Missing & Total & 47 & 92.2 & 100.0 & \\
\hline Total & System & 4 & 7.8 & & \\
\hline
\end{tabular}


Table 16. Production Skill Training

\begin{tabular}{|l|l|c|c|c|c|}
\hline \multirow{3}{*}{} & & Frequency & Percent & Valid Percent & $\begin{array}{l}\text { Cumulative } \\
\text { Percent }\end{array}$ \\
\hline \multirow{3}{*}{ Valid } & & & & & \\
& Very Useful & 2 & 3.9 & 4.3 & 15.0 \\
\cline { 2 - 6 } & Quite Useful & 5 & 9.8 & 10.9 & 45.1 \\
\cline { 2 - 6 } & Not Useful & 14 & 27.5 & 30.4 & 100.0 \\
\cline { 2 - 6 } & Not Available & 25 & 49.0 & 54.3 & 100.0 \\
\hline Missing & Total & 46 & 90.2 & & \\
\hline Total & System & 5 & 9.8 & & \\
\hline
\end{tabular}

Table 17. Management Training

\begin{tabular}{|l|l|c|c|c|c|}
\hline \multirow{2}{*}{} & & Frequency & Percent & Valid Percent & $\begin{array}{l}\text { Cumulative } \\
\text { Percent }\end{array}$ \\
\hline \multirow{3}{*}{ Valid } & & & & & \\
& Very Useful & 2 & 3.9 & 4.3 & 4.0 \\
\cline { 2 - 6 } & Quite Useful & 10 & 19.6 & 21.3 & 25.0 \\
\cline { 2 - 6 } & Not Useful & 9 & 17.6 & 19.1 & 44.0 \\
\cline { 2 - 6 } & Not Available & 26 & 51.0 & 55.3 & 100.0 \\
\hline \multirow{2}{*}{ Missing } & Total & 47 & 92.2 & 100.0 & \\
\hline Total & System & 4 & 7.8 & & \\
\hline
\end{tabular}

Table 18. Design Training

\begin{tabular}{|l|l|c|c|c|c|}
\hline \multirow{3}{*}{} & & Frequency & Percent & Valid Percent & $\begin{array}{c}\text { Cumulative } \\
\text { Percent }\end{array}$ \\
\hline \multirow{5}{*}{ Valid } & Very Useful & 2 & 3.9 & 4.3 & 4.0 \\
\cline { 2 - 6 } & Quite Useful & 8 & 15.7 & 17.0 & 21.0 \\
\cline { 2 - 6 } & Not Useful & 11 & 21.6 & 23.4 & 44.1 \\
\cline { 2 - 6 } & Not Available & 26 & 51.0 & 55.3 & 100.0 \\
\cline { 2 - 6 } & Total & 47 & 92.2 & 100.0 & \\
\hline Missing & System & 4 & 7.8 & & \\
\hline Total & & 51 & 100.0 & & \\
\hline
\end{tabular}




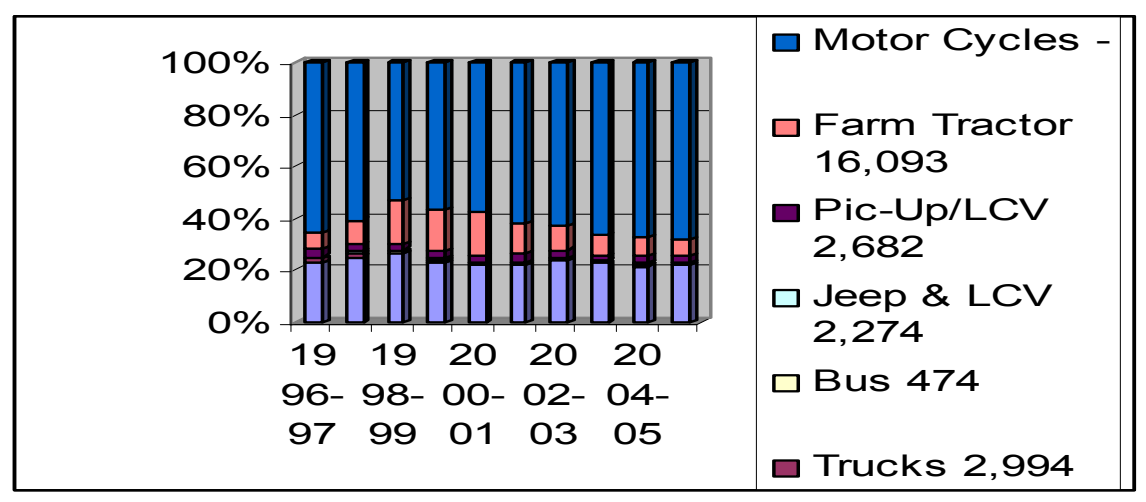

Figure 1.

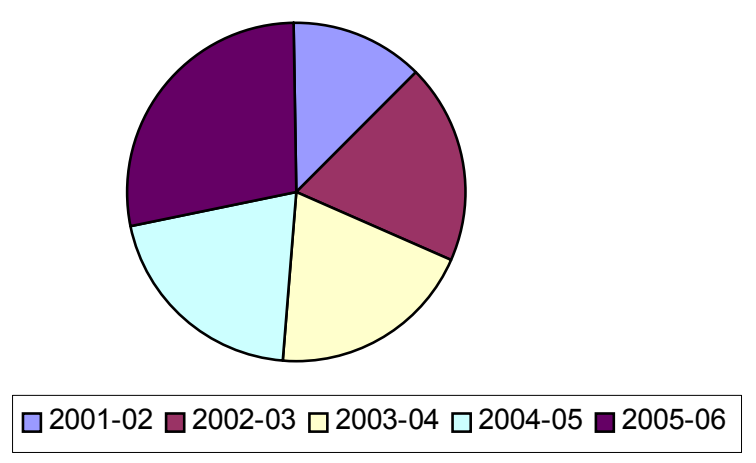

Figure 2. Export of Bed Wear from Pakistan during 2001-06 